\title{
ANALISIS TERJEMAHAN KALIMAT DALAM SURAT SPONSOR \\ COMPASS INTERNATIONAL FOUNDATION (KAJIAN IDEOLOGI, METODE, TEKNIK PENERJEMAHAN DAN KUALITASNYA)
}

\author{
Anastasia Inda Nugraheni, M.R. Nababan, Djatmika \\ Magister Linguistik Pascasarjana. Universitas Sebelas Maret \\ inda.anastasia@gmail.com
}

\begin{abstract}
Anastasia Inda Nugraheni. 2016. Analisis Terjemahan Kalimat Dalam Surat - Surat Sponsor Compass International Foundation (Kajian Ideologi, Metode, Teknik Penerjemahan dan Kualitasnya). Thesis. Linguistics Department of Post Graduate Program. Sebelas Maret University. Supervisor I: Prof. Drs. M.R. Nababan, M.Ed, M.A, Ph.D. Supervisor II: Prof. Dr. Djatmika, M.A. Surakarta.
\end{abstract}

The aims of the study are to identify types of sentences in the CIF sponsor letters and the text function or translation purpose in target text; to describe the translation techniques, methods, and ideology in achieving the translation purpose; to identify the impact of the translation techniques, methods, and ideology applied to the translation quality in terms of the accuracy of the accuracy, acceptability and readability; and to assess the translation techniques, methods and ideology selected in achieving the translation purpose.

This study is a descriptive, qualitative research and focused on a single case. Sources of the data were 10 pairs CIF sponsor letters and the informants who gave information about accuracy, acceptability and readability of translation. Techniques of collecting data were document analysis, queestionnaires and FGD. Purposive sampling was applied in this research.

Findings of this research show the followings. The types of sentenses are declaratives, interrogatives, imperatives and exclamatives. The result shows 15 functions of illocutionary act. There are 14 kinds of translation techniques to overcome the translation problems, $13,67 \%$ tends to the source text and $86,33 \%$ tents to the target text. The translation method tends to communicative translation method and free translation method with domestication ideology. The impact of the the application of those translation techniques, methods and ideology toward the quality of translation is satisfactory with the average score of 2,84 . This value indicates the accuracy, acceptance and readability of this translation is satisfactory. Related with the purpose of translation, the translation in this research successed in achieving text function or translation purpose.

Keywords: Translation, Translation technique, Translation method, Translation ideology, Translation quality 


\begin{abstract}
ABSTRAK
Penelitian ini yang bertujuan untuk mengidentifikasi jenis - jenis kalimat yang terdapat dalam surat sponsor Compass International Foundation (CIF) dan menentukan fungsi teks atau tujuan penerjemahannya; menganalisis teknik, metode, dan ideologi penerjemahan; melihat dampak teknik, metode dan ideologi penerjemahan terhadap kualitas terjemahan dari segi keakuratan, keberterimaan dan keterbacaan terjemahan; dan menilai penggunaan teknik, metode dan ideologi yang dipilih dalam mencapai tujuan penerjemahan.

Data dalam penelitian ini adalah kalimat dalam surat sponsor CIF. Sumber data adalah 10 pasang surat sponsor $C I F$, serta para informan (rater dan responden) yang berperan menilai keakuratan, keberterimaan dan keterbacaan penerjemahan surat.

Hasil yang ditemukan dalam penelitian ini adalah sebagai berikut. Data jenis jenis kalimat diklasifikasikan menjadi empat jenis yaitu: deklaratif,interogatif, imperatif dan eksklamatif serta ditemukan 15 kalimat berdasarkan fungsi ilokusi. Ada empat belas teknik penerjemahan yang digunakan penerjemah, 13,67\% mengarah ke bahasa sumber dan 86,33\% mengarah ke bahasa sasaran. Metode penerjemahan yang cenderung digunakan adalah metode penerjemahan komunikatif dan bebas dengan ideologi domestikasi.

Dampak dari pemilihan teknik, metode dan ideologi penerjemahan terhadap kualitas terjemahan baik dengan nilai rerata yang dihasilkan 2,84. Nilai ini mengindikasikan terjemahan memiliki kualitas keakuratan, keberterimaan dan keterbacaan yang baik. Bila dikaitkan dengan tujuan, maka terjemahan kalimat pada surat - surat sponsor CIF yang penulis teliti ini berhasil memenuhi tujuan penerjemahan.
\end{abstract}

Kata Kunci: Penerjemahan, Teknik Penerjemahan, Metode Penerjemahan, Ideologi penerjemahan, kualitas terjemahan

\title{
I. PENDAHULUAN
}

\section{Latar Belakang Penelitian}

Surat merupakan salah satu media yang digunakan manusia untuk berkomunikasi. Compass International Foundation (CIF) menjadikan surat sebagai salah satu media komunikasi utama antara para sponsor dengan anak asuh. Sponsor dapat berkomunikasi secara pribadi dengan anak asuh melalui surat - menyurat dengan difasilitasi oleh CIF. Kalimat - kalimat yang terdapat dalam surat sponsor kepada anak bisa memiliki dampak positif pada cara pandang anak akan kehidupan, diri - sendiri dan orang lain. Para sponsor didorong untuk didorong untuk menulis surat kepada anak asuh sesering yang mereka inginkan untuk membangun hubungan. Pengiriman surat sponsor 
kepada anak akan memastikan adanya dasar yang baik untuk suatu hubungan dan kesempatan bagi anak untuk mengalami dampak positif dari seorang sponsor yang terikat dan penuh kasih di dalam hidup anak tersebut.

Kalimat - kalimat yang terdapat dalam surat dari sponsor mampu menumbuhkan harapan, keteguhan hati dan kepercayaan bahwa anak mampu mengatasi segala tantangan yang menghadap dalam upaya mereka meraih masa depan yang lebih baik. CIF mengungkapkan bahwa dalam penelitian yang dilakukan di Peru, Rwanda, Guatemala, India bagian selatan dan Thailand menemukan : lebih dari 90\% anak sangat senang dan bahagia, tersemangati dan merasa memiliki hubungan kekeluargaan yang baik dan dekat ketika mereka medapatkan surat dari sponsor mereka; anak - anak yang menerima surat akan lebih sering berdoa dan memotivasi diri mereka sendiri untuk terus mengembangkan potensi diri; anak - anak yang menerima surat merasa lebih bersemangat bersekolah dan terlibat dalam kegiatan - kegiatan positif, mereka secara berkelanjutan menunjukkan tingkat kepercayaan diri yang bertumbuh dengan baik, terlebih mereka menunjukkan perhatian, keperdulian dan kerelaan berbagi dengan sesama, meningkatnya kemampuan berkomunikasi, kepatuhan dan keinginan untuk tolong - menolong; secara umum anak - anak yang menerima surat dari sponsor akan menyimpan surat - surat itu dengan sangat baik, membacanya seraca teratur, bahkan membacanya kembali disaat mereka membutuhkan penyemangat (YCI, 2012).

Penerjemah mempunyai tugas utama menyampaikan pesan, ide dan gagasan dari bahasa sumber (Bsu) ke bahasa sasaran (Bsa) secara tepat, utuh dan mudah dipahami oleh pembacanya, seperti yang dinyatakan oleh Newmark dalam definisinya tentang penerjemahan "Translation is a craft consisting in the attempt to replace a written 
message and/or statement in one language by same message/statement in another language” (1981).

Analisis kebahasaan yang dilakukan seorang penerjemah terhadap suatu teks bahasa sumber meliputi berbagai tataran seperti kalimat, klausa, frasa dan kata. Berbagai tataran terebut tersusun hingga menjadi suatu teks sehingga apa yang ingin diungkapkan oleh penulis dapat ditangkap maknanya dalam teks tersebut. Dalam menerjemahkan teks, penerjemah harus memahami isi teks. Maka penerjemah harus menguasai unsur linguistik dan ektralinguistik yang terkandung didalamnya. Nababan (2008) dalam bukunya menyatakan bahwa yang termasuk dalam unsur linguistik yaitu unsur kebahasaan sedangkan unsur ektralinguistik terkait dengan sosio budaya bahasa sumber serta makna yang terkandung dalam teks tersebut. Maka dapat dikatakan bahwa selain tata bahasa sumber (Bsu) dan bahasa sasaran (Bsa) yang mutlak dikuasai, pengetahuan tentang sosio budaya kedua bahasa juga menjadi faktor penentu keberhasilan seorang penerjemah dalam menerjemahkan dan berpengaruh pada kualitas terjemahan yang dihasilkan.

Dipilihnya surat sponsor CIF berbahasa Inggris dalam penelitian ini disebabkan oleh beberapa faktor. Faktor yang pertama ialah bahwa kalimat - kalimat dalam surat surat sponsor ini memiliki peranan yang sangat besar dalam menjaga dan meningkatkan kualitas hubungan antara sponsor dan anak yang disponsori. Berikutnya, kalimat dalam surat - surat sponsor memiliki peranan yang penting bagi kelangsungan masa depan anak yang disponsori dan anak- anak yang membutuhkan sponsor dimasa yang akan datang. Terakhir, surat - surat sponsor CIF berasal dari beberapa negara diberbagai belahan dunia, dan bahasa yang dipergunakan untuk menulis surat dalam bahasa asal sponsor, 
maka surat - surat sponsor yang dikaji adalah surat - surat sponsor yang asli berbahasa Inggris yang diterjemahkan ke dalam bahasa Indonesia.

\section{Tujuan Penelitian}

Tujuan penelitian ini adalah mengidentifikasi jenis - jenis kalimat yang terdapat dalam surat sponsor CIF dan menentukan fungsi teks atau tujuan penerjemahannya, menganalisis teknik penerjemahan apa yang dipilih penerjemah dalam mengatasi masalah penerjemahan guna mencapai fungsi teks yang dituju di teks sasaran, merumuskan metode penerjemahan apa yang digunakan penerjemah untuk mencapai tujuan penerjemahan atau fungsi teks, mengetahui ideologi penerjemahan bagaimana yang dianut penerjemah untuk menerjemahkan surat dari sponsor CIF untuk anak asuh di Indonesia, mengevaluasi teknik, metode dan ideologi penerjemahan terhadap kualitas terjemahan dengan parameter keakuratan, keberterimaan dan keterbacaan terjemahan.

\section{Kajian Pustaka}

Dalam bidang teori penerjemahan terdapat istilah translation dan interpretation yang digunakan dalam konteks yang berbeda - beda meskipun kedua istilah itu terfokus pada pengalih pesan dari bahasa sumber ke bahasa sasaran. Pada umumnya, istilah translation mengacu pada pengalihan pesan tertulis dan lisan. Namun, jika kedua istilah tersebut dibahas secara bersamaan, maka istilah translation menunjuk pada pengalihan pesan tertulis dan istilah interpretation mengacu hanya pada pengalihan pesan lisan. Perlu pula kita bedakan antara kata penerjemahan dan terjemahan sebagai padanan dari translation. Kata penerjemahan mengandung pengertian proses alih proses alih pesan, sedangkan kata terjemahan artinya hasil dari suatu penerjemahan (Nababan,2008). 
Teknik penerjemahan ialah cara yang digunakan untuk mengalihkan pesan dari Bsu ke Bsa, diterapkan pada tataran kata, frasa, klausa maupun kalimat. Oleh sebab itu, teknik penerjemahan dapat disebut sebagai realisasi dari proses pengambilan keputusan, yang hasilnaya dapat diidentifikasikan pada karya terjemahan. Molina dan Albir (2002:509) mendefinisikan teknik sebagai prosedur untuk menganalis dan mengklasifikasikan bagaimana kesepadanan terjemahan berlangsung dan dapat diterapkan pada berbagai satuan lingual. Menurut Molina dan Albir teknik penerjemahan memiliki lima karakteristik:

1. Teknik penerjemahan mempengaruhi hasil terjemahan

2. Teknik diklasifikasi dengan membandingkan Bsu dan Bsa

3. Teknik penerjemahan berada pada tataran mikro teks

4. Teknik penerjemahan bersifat diskursif dan kontekstual

5. Teknik penerjemahan bersifat fungsional

Metode atau method dalam Cobuild English Dictionary berarti "particular way of doing something". Sedangkan Molina dan Albir (2002:507) menyatakan "Translation method refers to the way a particular translation process is carried out in terms of the translators objective, i.e a global option that effect the whole text." Berdasarkan pendapat - pendapat diatas dapat diartikan bahwa metode penerjemahan merupakan pilihan cara penerjemahan pada tataran global yang terjadi dalam proses penerjemahan dan mempengaruhi teks secara keseluruhan terkait dengan tujuan penerjemahan.

Istilah "ideologi" dalam penerjemahan memiliki kesamaan dengan istilah tersebut dalam bidang lain. Ideologi penerjemahan mendasari setiap hal yang dilakukan oleh seorang penerjemah pada waktu menerjemahkan, termasuk penentuan 
metoda dan teknik - teknik yang digunakannya. Ideologi penerjemahan juga mempengaruhi pengambilan keputusan yang dilakukan oleh penerjemah tersebut, apakah cenderung berorientasi pada bahasa sumber atau bahasa sasaran. Secara umum, ideologi dalam penerjemahan dibagi menjadi dua bagian yaitu Domestikasi dan Foreignisasi. Ideologi yang cenderung berorientasi pada bahasa sasaran disebut domestikasi, sementara ideologi yang cenderung berorientasi pada bahasa sumber disebut foreignisasi.

Kualitas terjemahan telah menjadi perhatian banyak ahli penerjemahan. Mereka juga telah mengajukan berbagai macam metode dan instrumen untuk megukur kualitas terjemahan. Akan tetapi, metode - metode yang diajukan tersebut sebagian besar hanya bersifat parsial, yaitu hanya dapat digunakan untuk mengukur sebagian aspek yang menentukan kualitas terjemahan (Nababan, 2010).

Kualitas terjemahan ditentukan oleh tiga aspek yaitu keakuratan, keberterimaan dan keterbacaan. Ketiganya memegang peranan penting dan idealnya seorang penerjemah harus bisa menghasilkan terjemahan dengan tingkat keakuratan, keberterimaan dan keterbacaan yang tinggi (Nababan,2012). Namun, dengan berbagai macam pertimbangan dalam praktiknya terkadang sulit untuk menghasilkan terjemahan yang sempurna, seringkali seorang penerjemah menghadapi situasi ketika harus lebih mengutamakan aspek yang lain.

Dalam menerjemahkan teks dengan pembaca sasaran anak - anak pada dasarnya tidak berbeda dengan menerjemahkan teks untuk pembaca dewasa. Radegundis Stolze (2003) juga berpendapat bahwa menerjemahkan teks atau buku untuk anak sama seperti menerjemahkan teks untuk pembaca dewasa. Ia menyatakan bahwa penulis asli sudah menyesuaikan untuk anak - anak dengan menyatakan, "When 
children's books are being translated for children, the origional content is already adapted to the world of thought of children. So the translation could focus on its task of presenting the original text in another language”.

Penerjemah hanya perlu terfokus pada menyajikan teks bahasa sumber dalam bahasa sasaran. Penerjemah tidak perlu memikirkan isi teks yang diterjemahkan. Namun penerjemah perlu menyesuaikan isi terjemahan dengan norma dan nilai yang berlaku dalam budaya bahasa sasaran karena apa yang dianggap berterima dalam budaya bahasa sumber belum tentu berterima dalam budaya bahasa sasaran. Terjemahan istilah - istilah asing serta khas budaya sumber perlu disesuaikan dengan kemampuan dan pengetahuan anak, salah satunya dengan cara menerjemahkan dengan istilah - istilah yang mudah dipahami oleh anak - anak.

Unsur fungsi sintaksis dalam kalimat adalah subjek $(\mathrm{S})$, predikat $(\mathrm{P})$, objek $(\mathrm{O})$, pelengkap $(\mathrm{P})$ dan keterangan $(\mathrm{K})$. Setiap kalimat harus memiliki unsur sintaksis subjek dan predikat, sedangkan unsur lainnya (misalnya : objek, pelengkap, keterangan) merupakan unsur penunjang dalam kalimat. Secara sederhana Quirk (1985) menggolongkan kalimat dapat dibagi menjadi 4 jenis berdasarkan susunannya atau bentuknya, sebagai berikut : Dekraratif (Declaratives), Interogatif (Interrogatives), Imperatif (Imperatives) dan Eksklamatif (Exclamatives).

Quirk (1985) juga mengutarakan bahwa kalimat dapat dilihat dari makna yang terkandung dalam fungsi kalimat, dengan membaginya menjadi 4 jenis berdasarkan makna yang terkandung didalamnya atau melalui fungsi semantik. Kalimat - kalimat dalam surat merupakan ujaran dalam bentuk tulisan sehingga Illocutionary acts digunakan untuk pengidentifikasian maksud kalimat - kalimat dalam surat sponsor (the writer's meaning). Hal ini dikarenakan kalimat - kalimat pada surat sponsor 
merupakan ujaran atau tuturan dari sponsor kepada mitra tuturnya (anak asuh) yang dituangkan dalam bentuk tulisan. Searle (1975) mengemukan Illocutionary acts dikategorikan menjadi 5, yaitu : asertif (assertives), direktif (directives), komisif (commissives), ekspresif (expressives), dan deklaratif (declaratives).

\section{METODOLOGI}

Penelitian ini merupakan penelitian dalam bidang penerjemahan yang beorientasi pada produk karena menggunakan data yang berasal dari terjemahan kalimat - kalimat dalam surat berbahasa Inggris ke dalam bahasa Indonesia dari sponsor CIF untuk anak yang disponsori di Indonesia sebagaimana yang dikemukan oleh Nababan (2008:16) bahwa penelitian yang berorientasi pada karya terjemahan.

Metode yang digunakan dalam penelitian ini adalah metode kualitatif deskriptif. Penelitian ini merupakan studi kasus terpancang (embedded case study), Selain itu, penelitian ini juga menggunakan metode etnografi atau disebut juga field work. Hal ini disebabkan peneliti langsung turun lapangan mengambil data dari informan, dalam hal ini rater dan responden.

Selanjutnya, penelitian ini termasuk studi kasus tunggal karena sasaran atau subjeknya memiliki karakteristik yang sama (ibid dalam Santosa, 2014). Penelitian bidang penerjemahan seperti ini disebut Neubert (2004:10) juga sebagai limited case study atau case studies focusing on particular aspects of ST and TT. Ditinjau dari sisi orientasinya maka penelitian ini menurut Shuttle and Crowie (1997:131-132) termasuk penelitian dibidang penerjemahan yang berorientasi pada produk.

Menurut Spradley (1980, dalam Santosa, 2014) yang termasuk dalam lokasi penelitian adalah setting, participant, dan events. Setting atau tempat penelitian ini 
adalah surat - surat sponsor CIF kepada anak - anak asuhnya yang ada di Indonesia. Participant atau aktor yang terlibat didalamnya adalah, penulis surat atau para sponsor, CIF, penerjemah, dan pembaca surat (anak - anak yang disponsori / anak asuh). Selanjutnya event-nya adalah surat - surat yang berasal dari sponsor CIF berbahasa Inggris dan terjemahannya dalam bahasa Indonesia.

Data dalam penelitian ini adalah 10 pasang teks surat sponsor $C I F$ kepada anak - anak Indonesia yang menjadi anak asuhnya dalam versi bahasa Inggris dan bahasa Indonesia dan data informan, yaitu hasil kuesioner dan FGD terhadap rater/responden yang berperan menilai kualitas terjemahan dalam hal keakuratan, kerberterimaan dan keterbacaan. Rater yang dilibatkan dalam penelitian ini dipilih adalah informan yang ahli dalam bidang penerjemahan yang membantu menilai hasil terjemahan dari segi keakuratan dan keberterimaan. Dalam penelitian ini juga digunakan responden. Responden yang dilibatkan ialah pembaca sasaran teks terjemahan surat - surat sponsor tersebut dalam hal menilai kerterbacaan teks terjemahan.

Teknik sampling yang digunakan dalam penelitian ini adalah purposive sampling atau menggunakan sampling berdasarkan tujuan penelitian. Tujuan penelitian yang dimaksud yakni mengetahui secara detail tentang teknik penerjemahan, metode penerjemahan, ideologi penerjemahan dan dampak atau keterkaitan ketiga hal tersebut pada kualitas terjemahan. Dampak yang dimaksudkan terkait dengan tingkat keakuratan, keberterimaan dan keterbacaan hasil terjemahan.

Data penelitian yang dikaji terkait dengan aspek objektif dan afektif. Aspek objektif dalam hal ini adalah terjemahan surat sponsor yang dianalisis untuk mengetahui teknik, metode, dan ideologi yang diterapkan oleh penerjemah. 
Sementara aspek afektif merupakan tanggapan informan, dalam hal ini rater dan responden (pembaca awam). Tanggapan rater bertujuan untuk mengetahui tingkat keakuratan dan keberterimaan terjemahan. Sedangkan tanggapan responden atau pembaca awam bertujuan untuk mengetahui tingkat keterbacaan terjemahan.

\section{HASIL PENELITIAN DAN PEMBAHASAN}

\section{Bentuk dan Makna Kalimat}

Penelitian ini mengkaji kalimat - kalimat dalam surat sponsor CIF. Quirk (1985) mengutarakan bahwa kalimat dari susunan atau bentuknya meliputi deklaratif, interogatif, imperatif dan eksklamatif. Kalimat - kalimat dalam surat merupakan ujaran dalam bentuk tulisan, sehingga illocutionary acts digunakan untuk pengidentifikasian makna kalimat - kalimat pada surat sponsor (the writer's meaning). Kalimat - kalimat pada surat sponsor merupakan ujaran atau tuturan dari sponsor kepada mitra tuturnya (anak asuh) yang tertuang dalam bentuk tulisan. Setidaknya ada tiga pendapat ahli mengenai pembagian jenis illocutionary acts. Searle (1979) membagi menjadi lima jenis meliputi asertif, direktif, komisif, ekspresif dan deklarasi. George Yule (1996) membagi tindak tutur menjadi lima jenis fungsi umum, yaitu deklarasi, representatif, ekspresif, direktif, komisif. Kreidler (1998) membagi menjadi tujuh jenis yaitu fatis, performatif, komisif, ekspresif, verdiktif, asertif dan direktif. Ketiga pendapat tersebut berbeda dalam pembagian jenis, namun George Yule (1996) memiliki pembagian yang sama dengan pemikiran Quirk (1985). Temuan data berupa kalimat sebanyak 173 data diklasifikasikan sesuai dengan bentuk dan makna yang terkandung di dalamnya. Dalam setiap illocutionary acts mengandung suatu makna atau fungsi. Pada penelitian ini ada 15 macam meliputi berpendapat, memberi informasi, menerangkan, menasehati, berjanji, 
ungkapan senang, berterima kasih, berharap, ungkapan sayang, memuji, ungkapan bangga, meminta maaf, memberi selamat, bertanya, memohon atau meminta.

Kalimat - kalimat dalam surat sponsor yang ditujukan kepada anak asuh di teks sumber dan teks sasaran teridentifikasi bahwa bertujuan komunikatif, yaitu: untuk mempererat hubungan antara sponsor dengan anak asuh. Surat menjadi sarana sponsor mengungkapkan kepeduliannya terhadap anak asuhnya dengan menuangkan cerita keseharian mereka, keinginan mereka, berbagi harapan dan memberi pengharapan.

Komposisi kalimat dalam teks surat sponsor hampir sama, yaitu terdiri atas bentuk deklaratif $80,34 \%$; interogatif $16,18 \%$; imperatif $1,74 \%$ dan eksklamatif $1,16 \%$. Kalimat yang terkandung di dalamnya mengungkapkan makna sebagai berikut: menerangkan, memberi informasi, berharap, berpendapat, berterima kasih, senang, memuji, menasehati, bangga, berjanji, sayang, meminta maaf, memberi selamat, bertanya dan memohon atau meminta. Namun tidak semua jenis kalimat tersebut selalu ada di setiap teks surat. Terdapat dua jenis surat sponsor yaitu : surat balasan untuk surat anak yang telah diterima sebelumnya dan surat untuk anak asuhnya atas inisiatif sponsor sendiri.

Pada kedua jenis surat ini sama - sama terdapat kalimat deklaratif menerangkan $31,21 \%$; deklaratif memberi informasi 21,39\%; deklaratif berharap 8,09\%; deklaratif berpendapat 5,78\%; deklaratif memuji 2,31\%; deklaratif menasehati 1,16\%; deklaratif ungkapan bangga $1,16 \%$; deklaratif meminta maaf $1,16 \%$; imperatif meminta atau memohon $1,74 \%$ dan interogatif bertanya $16,18 \%$. Pada surat balasan untuk surat anak yang telah diterima sebelumnya terdapat kalimat - kalimat sebagai berikut: deklaratif berterima kasih 4,62\%; deklaratif ungkapan sayang 0,58\%; eksklamatif ungkapan senang $0,58 \%$ dan eksklamatif memuji $0,58 \%$. Serta surat untuk anak asuhnya atas inisiatif 
sponsor sendiri terdapat kalimat sebagai berikut: deklaratif ungkapan senang 2,31\% dan deklaratif berjanji $0,58 \%$.

Kalimat - kalimat yang terdapat dalam kedua jenis surat sponsor menunjukkan bahwa sponsor ingin berbagi tentang kehidupan kesehariannya dengan memberi informasi dan menerangkan tentang hal - hal yang terjadi di dalam kesehariannya, memberi dukungan dengan menumbuhkan harapan positif bagi masa depan anak, berbagi pemikiran dengan anak asuh dengan mengungkapkan pendapat, memberi apresiasi dengan memuji atas berkembangan yang terjadi dalam segala aspek kehidupan anak yang diketahui oleh sponsor, memberi petuah yang baik dalam kapasitasnya sebagai orang yang lebih dewasa, menghargai perasaan anak dengan tidak sungkan mengungkapkan maaf ketika melalaikan sesuatu, menyatakan rasa kebanggaannya terhadap anak asuh atas prestasi apapun yang dibuat anak, memberi perhatian lebih lanjut tentang apa yang terjadi dalam kehidupan anak dengan bertanya mengenai perkembangannya, serta mengutarakan keinginan atau permintaannya kepada anak.

Pada penelitian dari 173 data yang dikelompokkan berdasarkan bentuk kalimat dan fungsi atau makna yang terkandung di dalamnya, ditemukan 1 data mengalami pergeseran bentuk dan makna kalimat pada terjemahannya. Data tersebut dalam bahasa sumber merupakan kalimat eksklamatif memuji, sedangkan dalam bahasa sasaran bergeser menjadi deklaratif menyatakan.

\section{Teknik Penerjemahan}

Dalam mengatasi permasalahan yang ditemuinya, teridentifikasi penggunaan dua teknik penerjemahan tunggal dengan 22 data yang menerapkan varian ini. Dari dua teknik yang digunakan, teknik padanan lazim dan teknik modulasi. Ditemukan 10 varian 
teknik penerjemahan kuplet, dimana pada masing - masing varian ditemukan teknik padanan lazim. Varian teknik kuplet ini diterapkan dalam 78 data. Penelitian ini juga menemukan 18 varian teknik triplet yang diterapkan pada 56 data. Gabungan empat teknik yang diterapkan untuk menerjamahkan satu data atau biasa disebut varian teknik kwartet juga ditemukan dalam penelitian ini sebanyak 10 varian diterapkan pada 14 data. Selain varian teknik tunggal, kuplet, triplet dan kwartet ditemukan juga 3 data yang menerapkan perpaduan lima teknik penerjemahan atau disebut kwintet.

Dari gambaran di atas, tampak bahwa jumlah data yang diterjemahkan dengan teknik tunggal lebih sedikit dari yang diterjemahkan dengan teknik kuplet maupun teknik triplet. Hal ini disebabkan data yang diterjemahkan berada dalam tataran kalimat bukan tataran lingual dibawahnya, seperti kata atau frasa, sehingga memungkinkan dalam satu kalimat dipergunakan dua teknik, bahkan tiga sampai lima teknik sekaligus.

Tabel 1. Data Frekuensi Penggunaan Teknik Penerjemahan

\begin{tabular}{|c|c|c|c|c|c|c|c|c|c|c|c|c|c|c|}
\hline No & Orientasi & Teknik & $\bar{\Xi}$ & 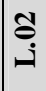 & 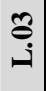 & 志 & $\stackrel{n}{\stackrel{2}{0}}$ & 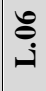 & $\stackrel{5}{\stackrel{S}{\circ}}$ & $\mid \begin{array}{l}\infty \\
\stackrel{\infty}{\hookrightarrow}\end{array}$ & 产 & 국 & $\Sigma$ & $\%$ \\
\hline 1 & \multirow{11}{*}{$\begin{array}{c}\mathrm{BSa} \\
360 \\
(86,33 \%)\end{array}$} & Padanan lazim & 16 & 14 & 20 & 35 & 19 & 12 & 17 & 13 & 17 & 7 & 170 & 40,77 \\
\hline 2 & & Variasi & 10 & 5 & 17 & 22 & 11 & 4 & 15 & 6 & 12 & 4 & 106 & 25,42 \\
\hline 3 & & Amplifikasi & 3 & 6 & 4 & 3 & 3 & 2 & 4 & 2 & 3 & 1 & 31 & 7,43 \\
\hline 4 & & Modulasi & 1 & 1 & 2 & 2 & 2 & 1 & 4 & 2 & - & - & 15 & 3,59 \\
\hline 5 & & Transposisi & - & 2 & 2 & 4 & 1 & 3 & 1 & 1 & - & - & 14 & 3,36 \\
\hline 6 & & Reduksi & - & 1 & 1 & - & 1 & 1 & 2 & 1 & - & - & 7 & 1,68 \\
\hline 7 & & Kompensasi & 1 & - & 2 & 1 & 1 & - & 1 & - & - & - & 6 & 1,44 \\
\hline 8 & & Amplifikasi linguistik & 1 & - & - & 1 & 1 & - & - & - & - & 1 & 4 & 0,96 \\
\hline 9 & & Partikularisasi & 1 & - & 1 & - & 1 & - & - & - & - & - & 3 & 0,72 \\
\hline 10 & & Kreasi diskursif & - & - & - & 1 & 1 & - & - & - & - & - & 2 & 0,48 \\
\hline 11 & & Kompresi linguistik & - & - & 1 & 1 & - & - & - & - & - & - & 2 & 0,48 \\
\hline 12 & \multirow{4}{*}{$\begin{array}{c}\mathrm{BSu} \\
57 \\
(13,67 \%) \\
\end{array}$} & Peminjaman & 7 & 1 & - & 15 & 5 & 4 & 3 & 3 & - & 2 & 40 & 9,59 \\
\hline 13 & & Harfiah & 1 & 1 & 2 & 2 & - & - & 1 & - & 3 & 1 & 11 & 2,64 \\
\hline 14 & & Kalke & - & - & - & - & - & - & - & - & 3 & 3 & 6 & 1,44 \\
\hline & & $\Sigma$ & 41 & 31 & 52 & 87 & 46 & 27 & 48 & 28 & 38 & 19 & 417 & 100 \\
\hline
\end{tabular}

Teknik padanan lazim merupakan teknik penerjemahan yang paling banyak digunakan, hal ini sesuai dengan perkiraan. Sebagai teks yang diperuntukkan untuk memperat hubungan antara anak asuh dengan sponsor, maka dugaan terbesar adalah teks akan diterjemahkan dengan teknik penerjemahan yang condong ke bahasa sasaran, 
seperti teknik padanan lazim, variasi, amplifikasi, modulasi, transposisi, reduksi, kompensasi, amplifikasi linguistik, partikularisasi, kreasi diskursif, kompresi linguistik dan sebagainya.

Tingginya tingkat penggunaan teknik padanan lazim dalam penelitian ini disebabkan oleh pilihan wacana yang dibentuk. Pada surat - surat sponsor untuk anak asuhnya umumnya menggunakan bentuk prosa narasi, sehingga banyak istilah keseharian yang biasa dijumpai dalam kehidupan keseharian. Istilah - istilah keseharian ini tentunya hampir semuanya memiliki padanan dalam bahasa sasaran, dalam penelitian ini Bahasa Indonesia.

Teknik penerjemahan kedua yang banyak digunakan adalah teknik penerjemahan variasi. Selanjutnya secara berturut - turut penggunaan teknik penerjemahan dalam teknik ini adalah amplifikasi, modulasi, transposisi, reduksi, kompensasi, amplifikasi linguistik, partikularisasi, kreasi diskursif, kompresi linguistik. Terdapat juga penggunaan teknik penerjemahan peminjaman, harfiah dan kalke dalam penerjemahan kalimat dalam surat - surat sponsor $C I F$.

Pada penelitian ini, agar dapat mengalih bahasakan kalimat dengan baik seringkali diperlukan kombinasi beberapa teknik penerjemahan yang terdiri antara dua sampai dengan lima teknik penerjemahan. Perbedaan budaya pada teks sumber dan budaya pada teks sasaran menimbulkan banyak persoalan sehingga banyak kalimat atau kata yang mesti dimodifikasi dengan perbagai cara seperti direduksi, diparafrase, maupun diperkuat dengan amplifikasi agar menghasilkan teks yang dapat diterima dalam budaya sasaran. Semua teknik yang diterapkan memiliki tujuan agar teks bahasa sasaran yang direkonstruksi mudah dipahami pembaca. 


\section{Metode Penerjemahan}

Kalkulasi dari seluruh surat, teknik penerjemahan yang berorientasi pada bahasa sasaran digunakam sebanyak 360 kali, sedangkan frekuensi penggunaan teknik penerjemahan yang berorientasi pada bahasa sumber adalah 57 kali. Dapat dikatakan bahwa penerjemahan kalimat dalam surat - surat yang diteliti ditemukan bahwa surat 86,33\% memiliki kecenderungan menggunakan metode penerjemahan yang mengarah pada bahasa sasaran dan $13,67 \%$ memiliki kecenderungan menggunakan metode penerjemahan yang mengarah pada bahasa sumber.

Penerjemahan dalam penelitian ini menemukan empat metode penerjemahan, yaitu: dua metode penerjemahan yang mengarah pada bahasa sumber dan dua metode yang mengarah pada bahasa sasaran. Sebagian besar penerjemahan dalam penelitian ini menerapkan metode penerjemahan yang berorientasi pada bahasa sasaran, yaitu: metode penerjemahan komunikatif dan metode penerjemahan bebas. Sebagian kecil lainnya menerapkan metode penerjemahan berorientasi pada bahasa sumber, yaitu: metode penerjemahan setia dan metode penerjemahan harfiah.

\section{Ideologi Penerjemahan}

Penerapan teknik penerjemahan kalimat dalam surat - surat yang diteliti terdapat $86,33 \%$ memiliki kecenderungan menggunakan metode penerjemahan yang mengarah pada bahasa sasaran dan $13,67 \%$ memiliki kecenderungan menggunakan metode penerjemahan yang mengarah pada bahasa sumber. Dengan demikian dapat disimpulkan bahwa sebagian kecil kalimat dalam surat - surat tersebut menganut ideologi foregnisasi dan hampir seluruh kalimat dalam surat - surat tersebut menganut ideologi domestikasi. 
Tingginya frekuensi penerjemahan yang menganut ideologi domestikasi menandakan bahwa hampir semua penerjemahan kalimat dalam surat yang diteliti hendak memenuhi fungsi di teks sasaran, yaitu terjemahan yang dekat dengan bahasa dan budaya sasaran. Penerjemah memahami benar bahwa teks surat adalah teks yang digunakan untuk mempererat hubungan emosional antara sponsor dan anak, sehingga kepentingan pembaca sasaran harus lebih diperhatikan. Sebagian kecil penerapan teknik penerjemahan pada penerjemahan kalimat surat dinilai tidak mencapai tujuan penerjemahannya, karena memilih untuk setia pada teks bahasa sumber dengan memilih ideologi foregnisasi dan metode penerjemahan yang mengarah ke bahasa sumber, yaitu metode penerjemahan setia dan metode penerjemahan harfiah. Dengan demikian, pemilihan teknik penerjemahan yang digunakan penerjemah untuk mengatasi masalah penerjemahan di tingkat mikro untuk menghadirkan terjemahan yang sesuai dengan budaya dan bahasa sasaran sebagian besar dinilai berhasil dengan dipilihnya ideologi domestikasi dan penerapan metode penerjemahan kamunikatif dan metode penerjemahan bebas di tingkat makro yang berorientasi ke bahasa sasaran.

\section{Kualitas Terjemahan}

Dalam penelitian ini didapat 173 data. dari 173 data tersebut didapat 154 data dengan terjemahan yang akurat, 19 data diterjemahkan dengan kurang akurat, dan tidak ada data yang tidak akurat. Dari segi keberterimaan didapatkan 135 data masuk dalam kategori berterima, 37 data masuk dalam kategori kurang berterima dan satu data masuk dalam kategori tidak berterima. Kemudian dari segi keterbacaan didapatkan 141 data

masuk dalam kategori berketerbacaan tinggi, 31 data masuk dalam kategori berketerbacaan sedang dan 1 data masuk dalam kategori berketerbacaan rendah. 
Perhitungan skor rerata dari ketiga aspek keakuratan, keberterimaan dan keterbacaan adalah surat pertama 2,86; surat kedua 2,80; surat ketiga 2,75; surat keempat 2,86; surat kelima 2,85; surat keenam 2,79; surat ketujuh 2,83; surat kedelapan 2,91; surat kesembilan 2,79 dan surat kesepuluh 2,92. Skor rerata dari sepuluh teks yang dianalisis dalam penelitian ini adalah 2,84. Skor masing - masing teks dan skor rerata teks pada penelitian ini menggambarkan bahwa secara keseluruhan terjemahan kalimat pada surat sponsor $C I F$ bisa dikatakan akurat, berterima dan mudah dipahami oleh pembaca sasaran.

\section{Pengaruh Teknik, Metode, dan Ideologi Pada Kalimat Terhadap Kualitas terjemahan}

Penelitian ini menunjukkan bahwa penilaian kualitas terjemahan yang dilakukan pembaca ahli maupun pembaca sasaran memiliki proyeksi yang sama. Hal ini terbukti nilai keakuratan, keberterimaan dan keterbacaan yang tinggi, sehingga menghasilkan skor kualitas terjemahan yang tinggi juga. Skor kualitas terjemahan yang tinggi ini menunjukkan bahwa kualitas terjemahan kalimat dalam surat - surat sponsor CIF memang tidak sempurna akan tetapi berdasarkan penelitian ini memiliki kualitas yang baik.

Ketiga aspek kualitas terjemahan yang bernilai tinggi dan mendapatkan kategori yang baik bisa dicapai karena ideologi, metodelogi dan teknik - teknik yang digunakan tepat dan memiliki berbagai varian, sehingga distorsi makna bisa dihindari, mudah dipahami, dan berterima dalam kaidah - kaidah bahasa sasaran serta budaya bagi budaya

pembaca sasaran. Hal ini dibuktikan melalui kombinasi teknik - teknik yang diterapkan terhadap kualitas terjemahan, yaitu: teknik penerjemahan tunggal 22 data, kombinasi dua 
teknik 78 data, kombinasi tiga teknik 56 data, kombinasi empat teknik 14 data dan kombinasi lima teknik 3 data.

Pada kalimat dalam surat sponsor $C I F$ terdapat 17 jenis kalimat yang ditemukan dalam penelitian ini. Penelitian terhadap kalimat deklaratif berjanji, kalimat deklaratif ungkapan senang, kalimat deklaratif ungkapan sayang, kalimat deklaratif meminta maaf, kalimat deklaratif memberi selamat, kalimat imperatif meminta, kalimat eksklamatif ungkapan senang dan kalimat deklaratif memuji dalam penelitian ini diterjemahkan secara akurat, berterima dan berketerbacaan tinggi secara keseluruhan (100\%). Penerjemahan 14 data tersebut menerapkan berbagai varian teknik berupa tiga data varian teknik tunggal, lima data varian teknik kuplet, empat data varian teknik triplet dan satu varian teknik kwartet.

Pada penerjemahan kalimat deklaratif berpendapat, kalimat deklaratif memberi informasi, kalimat deklaratif menasehati, kalimat deklaratif berterima kasih, kalimat deklaratif berharap, kalimat deklaratif memuji, kalimat deklaratif ungkapan bangga, kalimat deklaratif memberi selamat hampir semua data memiliki penerjemahan yang akurat, berterima dan berketerbacaan tinggi. Namun terdapat beberapa data dalam jumlah kecil yang memiliki nilai kurang akurat, kurang berterima atau berketerbacaan sedang. Penerjemahan 88 data tersebut menerapkan berbagai varian teknik berupa dua belas varian teknik tunggal, tiga puluh dua varian teknik kuplet, dua puluh lima varian teknik triplet, delapan varian kwartet dan satu varian kwintet.

Kemudian penerjemahan kalimat deklaratif menerangkan dan kalimat interogatif bertanya hampir semua data memiliki penerjemahan yang akurat, berterima dan berketerbacaan tinggi. Namun terdapat satu data pada kalimat deklaratif menerangkan penerjemahannya tidak berterima dan satu data pada kalimat interogatif 
mendapatkan penilaian keterbacaan rendah. Penerjemahan 71 data tersebut menerapkan berbagai varian teknik berupa enam varian teknik tunggal, tiga puluh sembilan varian teknik kuplet, dua puluh satu varian teknik triplet, empat varian kwartet dan satu varian kwintet.

Kombinasi teknik, metode dan ideologi penerjemahan ini telah membawa memberi kontribusi yang baik terhadap kualitas hasil terjemahan. Penerjemahan kalimat dalam surat - surat sponsor CIF memerlukan ketiga aspek kualitas terjemahan, sebagaimana yang dijelaskan oleh Nababan (2012) bahwa terdapat tiga kriteria kualitas terjemahan yang baik yaitu: keakuratan (accuracy), keberterima (acceptability) dan keterbacaan (readability). Beberapa pakar berpendapat bahwa keakuratan pesan merupaka suatu konsep yang relatif. Hal ini bisa diartikan bahwa pernyataan tentang terjemahan yang akurat tergantung pada orang yang menilainya. Dengan demikian terdapat asumsi bahwa indikator penilaian masih bersifat subjektif untuk menentukan tingkat kesetiaan teks bahasa sasaran pada teks bahasa sumbernya. Kesepadanan yang tinggi dalam penerjemahan juga merupakan hal yang sulit dicapai, karena dalam praktek penerjemahan padanan satu lawan satu tidak selalu bisa ditemukan. Akan tetapi perlu dipahami bahwa muara dari proses penerjemahan adalah pembaca. Sehingga budaya, lingkungan, ekspektasi dan kebutuhan komunikasi pembaca merupakan hal - hal penting yang harus dipertimbangkan dalam penerjemahan.

\section{PENUTUP}

\section{Simpulan}

Berdasarkan hasil analisis dan pembahasan pada bab - bab sebelumnya, maka dapat ditarik kesimpulan sebagai berikut: 
1. Dari 173 data yang dianalisis dapat disimpulkan bahwa kalimat - kalimat yang terdapat dalam surat - surat sponsor $C I F$ terdiri dari empat macam bentuk kalimat, yaitu: kalimat deklaratif 140 data, kalimat interogatif 28 data, kalimat imperatif 3 data dan kalimat eksklamatif 2 data. Masing - masing bentuk kalimat memiliki makna yang terkandung didalamnya dengan fungsi sebagai berikut: kalimat deklaratif menerangkan 54 data, kalimat deklaratif memberi informasi 37 data, kalimat deklaratif berharap 14 data, kalimat deklaratif berpendapat 10 data, kalimat deklaratif berterima kasih 8 data, kalimat deklaratif ungkapan senang 4 data, kalimat deklaratif memuji 4 data, kalimat deklaratif menasehati 2 data, kalimat deklaratif ungkapan bangga 2 data, kalimat deklaratif meminta maaf 2 data, kalimat deklaratif berjanji 1 data, kalimat deklaratif ungkapan sayang 1 data, kalimat deklaratif memberi selamat 1 data, kalimat interogatif bertanya 28 data, kalimat imperatif meminta 3 data, kalimat eksklamatif ungkapan senang 1 data dan kalimat eksklamatif memuji 1 data.

2. Penerapan teknik yang digunakan dalam penerjemahan kalimat dalam surat - surat menggunakan 14 teknik yang memiliki orientasi ke bahasa sumber dan orientasi ke bahasa sasaran. Teknik yang berorientasi pada bahasa sumber adalah padanan lazim, variasi, amplifikasi, modulasi, transposisi, reduksi dan kompensasi linguistik dengan penerapan 360 kali. Sedangkan teknik yang berorientasi pada bahasa sumber adalah peminjaman, harfiah dan kalke dengan penerapan 57 kali. Metode penerjemahan yang diterapkan dalam penerjemahan kalimat - kalimat dalam surat sponsor $C I F$ ini adalah metode penerjemahan komunikatif $(82,49 \%)$, metode penerjemahan setia $(11,03 \%)$, metode penerjemahan bebas $(3,84 \%)$ dan metode penerjemahan Harfiah (2,64\%). 
3. Metode penerjemahan diterapkan memiliki orientasi bahasa yang berlawanan. Metode penerjemahan harfiah yang terdiri dari teknik harfiah; dan metode penerjemahan setia yang terdiri dari teknik peminjaman dan teknik kalke merupakan metode penerjemahan yang berorientasi pada bahasa sumber dengan ideologi forengnisasi. Sedangkan metode penerjemahan komunikatif yang terdiri dari teknik padanan lazim, teknik variasi, teknik amplifikasi, teknik transposisi, teknik reduksi, teknik kompensasi, teknik amplifikasi linguistik, teknik partikularisasi, teknik kompresi linguistik; dan metode penerjemahan bebas yang terdiri dari teknik modulasi dan teknik kreasi diskursif merupakan metode penerjemahan yang berorientasi pada bahasa sasaran dengan ideologi domestikasi. Penelitian ini menemukan bahwa penggunaan teknik dengan orientasi bahasa sasaran sangat dominan (86,33\%), sehingga ideologi yang memayungi penerjemahan kalimat dalam surat - surat sponsor CIF cenderung ideologi berorientasi budaya dan bahasa sasaran seperti ideologi domestikasi.

4. Skor rerata dari sepuluh teks yang dianalisis dalam penelitian ini adalah 2,84 menggambarkan bahwa secara keseluruhan terjemahan kalimat pada surat sponsor CIF bisa dikatakan akurat, berterima dan mudah dipahami oleh pembaca sasaran. Penelitian ini menunjukkan bahwa penilaian kualitas terjemahan yang dilakukan pembaca ahli maupun pembaca sasaran memiliki proyeksi yang sama. Hal ini terbukti nilai keakuratan, keberterimaan dan keterbacaan yang tinggi, sehingga menghasilkan skor kualitas terjemahan yang tinggi juga. Skor kualitas terjemahan yang tinggi ini menunjukkan bahwa kualitas terjemahan kalimat dalam surat surat sponsor $C I F$ memang tidak sempurna akan tetapi berdasarkan penelitian ini memiliki kualitas yang baik. 


\section{Implikasi}

Penelitian ini adalah studi terhadap produk terjemahan surat pribadi dalam hal ini surat dari sponsor kepada anak asuhnya dengan CIF sebagai perantara, khususnya mengenai kualitas terjemahan kalimat berdasarkan bentuk dan maknanya serta penerapan teknik, metode dan ideologi penerjemahannya.

Kalimat - kalimat dalam surat sponsor yang ditujukan kepada anak asuh di teks sumber dan teks sasaran teridentifikasi bahwa bertujuan komunikatif, yaitu: untuk mempererat hubungan antara sponsor dengan anak asuh. Surat menjadi sarana sponsor mengungkapkan keperduliannya terhadap anak asuhnya dengan menuangkan cerita keseharian mereka, keinginan mereka, berbagi harapan dan memberi pengharapan.

Terdapat dua jenis surat sponsor yaitu surat balasan untuk surat anak yang telah diterima sebelumnya dan surat untuk anak asuhnya atas inisiatif sponsor sendiri. Kalimat - kalimat yang terdapat dalam kedua jenis surat sponsor menunjukkan bahwa sponsor ingin berbagi tentang kehidupan kesehariannya dengan memberi informasi dan menerangkan tentang hal - hal yang terjadi didalam kesehariannya, memberi dukungan dengan menumbuhkan harapan positif bagi masa depan anak, berbagi pemikiran dengan anak asuh dengan mengungkapkan pendapat, memberi apresiasi dengan memuji atas berkembangan yang terjadi dalam segala aspek kehidupan anak yang diketahui oleh sponsor, memberi petuah yang baik dalam kapasitasnya sebagai orang yang lebih dewasa, menghargai perasaan anak dengan tidak sungkan mengungkapkan maaf ketika melalaikan sesuatu, menyatakan rasa kebanggaannya terhadap anak asuh atas prestasi apapun yang dibuat anak, memberi perhatian lebih lanjut tentang apa yang terjadi dalam kehidupan anak dengan 
bertanya mengenai perkembangannya, serta mengutarakan keinginan atau permintaannya kepada anak.

Pada surat balasan untuk surat anak yang telah diterima sebelumnya dan surat untuk anak asuhnya atas inisiatif sponsor sendiri selain berisi kalimat - kalimat yang mengungkapkan hal - hal yang diuraikan pada paragraf diatas, kedua jenis surat ini memiliki sedikit perbedaan isi kalimat didalamnya. Surat balasan untuk surat anak yang telah diterima sebelumnya didalamnya terdapat ungkapan terima kasih atas surat dan hasta karya atau foto yang diterima sponsor dari anak asuhnya, ungkapan perasaan emosional sayang yang dirasakan sponsor untuk anak asuhnya, memberi ucapan selamat atas hal - hal baik yang terjadi pada anak, berbagi perasaan senang atas apa yang terjadi pada kehidupan sponsor, memberi dorongan positif dengan memberi pujian atas apa yang diraih anak. Sedangkan pada surat untuk anak asuhnya atas inisiatif sponsor sendiri didalamnya juga terdapat ungkapan senang bisa menulis surat untuk anak asuh, membuat komitmen tentang sesuatu yang berhubungan dengan anak asuh. Dengan demikian dapat dikemukakan bahwa komunikasi lewat surat - menyurat yang terjalin antara sponsor dan anak asuhnya sangat penting bagi kedua pihak yang terhubung didalamnya.

Penerapan teknik penerjemahan padanan lazim, variasi, amplifikasi, modulasi, transposisi yang berorientasi pada bahasa sasaran sangat sesuai diterapkan untuk menerjemahkan kalimat - kalimat dalam surat sponsor $C I F$ dari bahasa sumber ke bahasa sasaran. Penerjemah akan menghasilkan terjemahan yang memenuhi fungsi teks jika menggunakan landasan ideologi domestikasi dengan memilih metode komunikatif sebagai metode penerjemahannya. 


\section{Saran}

Berdasarkan hasil analisis data dan simpulan, maka peneliti menyarankan beberapa hal sebagai berikut:

a. Penerjemah surat sponsor $C I F$ akan lebih baik jika penerjemah lebih memperhatikan kaidah yang berlaku dalam Bahasa Indonesia sebagai bahasa sasaran dan memperhatikan pilihan kata yang digunakan dalam terjemahan agar keakuratan, keberterimaan dan keterbacaan kalimat dapat ditingkatkan. Hal penting yang harus diperhatikan adalah pembaca surat terjemahan merupakan pembaca yang dikategorikan sebagai anak, sehingga diperlukan terjemahan yang tersusun sederhana dan mudah dipahami.

b. Semua informasi dalam teks bahasa sumber merupakan komponen penting dari suatu teks. Maka pengurangan, penghilangan atau tidak diterjemahkannya suatu informasi dapat mempengaruhi kualitas terjemahan, sehingga penerapan teknik reduksi harus dilakukan dengan pertimbangan yang baik.

c. Teknik amplifikasi dengan eksplisitasi maupun adisi bertujuan memperjelas makna dan konsep yang terkandung dalam bahasa sumber yang ingin disampaikan oleh penulis kepada pembaca sasaran. Namun penggunaan teknik ini harus dilakukan secara proporsional, sehingga tepat guna dan tidak menjadi penambahan yang tidak efisien.

d. Penerjemah sebaiknya mengurangi penggunaan istilah asing dengan merujuk pada istilah yang mudah dipahami pembaca, terlebih dalam penelitian ini pembaca sasaran adalah anak - anak.

e. Penelitian ini berorientasi pada produk, yaitu mengidentifikasi jenis kalimat, menganalisa teknik, metode dan ideologi yang diterapkan pada penerjemahan 
kalimat pada surat - surat sponsor $C I F$. Dengan menggunakan sumber data yang sama, perlu dilakukan penelitian lanjutan yang berorientasi pada proses penerjemahan teks surat yang merupakan tuturan dalam bentuk tulisan.

\section{DAFTAR PUSTAKA}

Alwi, et al. 2003. Tata Bahasa Baku Bahasa Indonesia. Jakarta: Balai Pustaka.

Catford, J.C. 1974. A Linguistics Theory of Translation. London: Oxford University

Fawcett, P. 1997. Translation and language: Linguistic theories explained.

Haryanta, A. T. 2012. Kamus Kebahasaan dan Kesusastraan, Surakarta: Aksara Sinergi Media

Moleong, L. J. 1989. Metodologi Penelitian Kualitatif (Qualitative Research Methodology). Jakarta: Remaja Karya.

Molina, L \& Albir, H. 2002. Translation Techniques Revisited: A Dynamic and Functionalist Approach. Barcelona: Universitat Autonoma de Barcelona. Dalam Meta: Translators' Journal XLVII, 4.

Nababan,M.R. 2003. Teori Menerjemahkan Bahasa Inggris. Yogyakarta: Pustaka Pelajar 2007. Aspek Genetik, Objektif, dan Afektif dalam Penelitian Penerjemahan. Surakarta: Universitas Sebelas Maret . 2008. Teori Menerjemahkan Bahasa Inggris. Yogyakarta: Pustaka Pelajar . 2010. Teknik - Teknik Penerjemahan Teks. Unpublished paper presented in National Seminar of Translation in Widya Mandala University Madiun , Ardiana. N \& Sumardiono. 2012. Pengembangan Model Penilaian Kualitas Terjemahan. Surakarta: Universitas Sebelas Maret Surakarta

Newmark, Peter. 1981. Approaches to Translation. Oxford: Pergamon Press 1988. A Textbook of Translation. London: Prentice Hall

Nida, E. A and Taber. 1974. The Theory and Practice of Translation. Netherland. Leiden: E.J. Brill

Nord, Christine. 2005. Text Analysis in Translation: Theory, Methodology, and Didactic Application of a Model for Translation - Oriented Text Analysis. Second Edition. Rodopi. 
Quirk, Randolph. 1985. A Comprehensive Grammar of The English Language. . London: Longman

Santosa, Riyadi. 2014. Draft Buku Metode Penelitian Kualitatif Kebahasaan (Draf buku), Surakarta: Fakultas Sastra dan Seni Rupa

Searle, J.R. 1979. Expression and meaning. UK: Cambridge University Press

Sugiyono. 2010. Metode Penelitian Kuantitatif, Kualitatif dan $R \& D$. Bandung: Penerbit Alfabeta

Sutopo. 2006. Metodologi Penelitian Kualitatif. Surakarta: UNS Press

YCI. 2012. Buku panduan Kemitraan. Bandung. C's Project.

Yule, George. 1996. Pragmatics. Oxford University Press 